ELORE (ISSN 1456-3010), vol. $16-1 / 2009$.

Julkaisija: Suomen Kansantietouden Tutkijain Seura ry. [http://www.elore.fi/arkisto/1_09/kirjat_enges2_01_09.pdf]

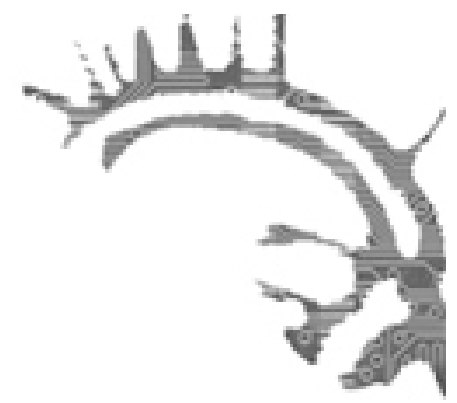

\title{
KIRJA-ARVIO:
}

\section{ROMANIMUSIIKKIA MAHTILAULUISTA TANGOON}

Aberg, Kai \& Blomster, Risto (toim.) 2006: Suomen romanimusiikkki. Suomalaisen Kirjallisunden Seuran Toimituksia 1058. Helsinki: SKS. 288 sivua.

\section{Pasi Enges}

Herderiläiset näkemykset kansanrunoudesta kollektiivisen kansansielun ilmentäjänä nousevat helposti mieleen, kun näkee korostettavan jokin kansan tai ryhmän poikkeuksellista kykyä ja herkkyyttä taiteelliseen itseilmaisuun. Suomen tällä hetkellä noin kymmentuhantinen romanivähemmistö edustaa kulttuuria, johon usein liitetään tällaisia vahvasti romanttisia mielikuvia. Romanilaulajien ja -soittajien esityksissä ollaan kuulevinaan "jotakin tunteellisesti syvempää ja luonnollisempaa" kuin valtaväestön lauluissa ja romaneja kuvataan tunteitaan estoitta ilmaiseviksi, "laulu verissä syntyneiksi” luonnonlapsiksi. Mihin tällaiset käsitykset perustuvat ja kenen näkökantaa ne edustavat?

Muun muassa stereotypiaa romanien myötäsyntyisestä musikaalisuudesta käsitellään Kai Åbergin ja Risto Blomsterin toimittamassa artikkelikokoelmassa Suomen romanimusiikki, joka on lajissaan ensimmäinen tutkimukseen pohjautuva yleisesitys Suomen romanien musiikkikulttuureista. Kirjan viidestä kirjoittajasta kahden tekstit ovat aiemmin ilmestyneiden artikkelien uudelleenjulkaisuja. Uusista teksteistä vastaavat teoksen toimittajat joko yksin tai yhteistyössä.

Kirjan aloitus- ja samalla eräänlaiseksi avaintekstiksi on valittu Pekka Jalkasen alun perin vuonna 1976 julkaistu ja nyt muuttamattomana painettu artikkeli Suomen mustalaisten musiikista. Tekstin sijoittamista erilleen kokoelman muista artikkeleista toimittajat perustelevat sen erityisellä, suuntaa antavalla merkityksellä myöhemmälle romanimusiikin tutkimukselle. Totta onkin, että suppeassa tekstissään Jalkanen onnistuu avaamaan monta langanpäätä. Hän esittää romanimusiikin suomalaisen ja kansainvälisen historian päälinjat, nykytilanteen ja valottaa hieman myös sen tulevaisuuden näkymiä 1970-luvulla. Romanimusiikki on sävelmistön ja tekstien osalta paljolti valtaväestöltä lainattua, eikä eri maiden romanimusiikkiperinteillä ole tässä 


\section{ROMANIMUSIIKKIA MAHTILAULUISTA TANGOON}

suhteessa paljon yhteistä. Esitystapansa ja monien tyylipiirteidensä puolesta se sen sijaan eroaa valtaväestön musiikista jyrkästi, mutta on läheistä muiden Euroopan maiden romanien musiikkitraditioille. Musiikki on tulkittavissa romanikulttuurissa yhtäältä vanhakantaiseksi vähemmistöidentiteetin ylläpitäjäksi, mutta toisaalta siinä heijastuu yhteiskunnallisia muutoksia myötäilevän vähemmistön sopeutumis- ja uudistumiskyky.

\section{MuistinVARAisia LAULUja OMASTA ELÄMÄSTÄ}

Avausartikkelin jälkeen kirja jakautuu kolmeen osaan, joissa syvennetään Jalkasen esittämiä tai otetaan käsittelyyn hänen ohittamiaan aiheita ajantasaisen tutkimustiedon valossa. Kukin kirjan osista koostuu kolmesta artikkelista. Ensimmäisenä käsitellään Suomen romaniväestön perinnemusiikkia ja tarkastelun kohteina ovat romanilaulujen aiheet, melodiikka ja esitystyylit.

Kokoelman sivumäärältään laajin teksti - yli seitsemänkymmentä sivua - on omistettu romanilaulujen aihepiirien erittelylle. Kai Åberg perustaa esityksen omiin kenttätöihinsä, joita hän on tehnyt lähinnä itäsuomalaisen romaniväestön parissa 1900-luvun viimeisellä kymmenellä ja uuden vuosituhannen alussa; käsittelyssä on siis elinvoimainen ja edelleen ajankohtainen laulukulttuuri. Romanilaulujen suhde suomalaiseen kansanlauluun, omakielisten laulujen asema, laulutekstien tyylipiirteet ja keskeiset lauluperinteen lajit ovat artikkelissa käsiteltyjä aiheita. Lauluista löytyy suoria yhteyksiä romanikulttuurin kokonaisuuteen: elinkeinot, työnjako sekä kulttuurin arvo- ja normijärjestelmä heijastuvat lauletussa. Haastatteluaineistosta poimitut, laulajien itsensä esittämät laulua ja laulamista koskevat tulkinnat tuovat tällaiseen tarkastelutapaan lisäsyvyyttä ja vakuuttavuutta.

Åbergin lähestymistavassa laulujen aiheisiin korostuu sukupuolinäkökulma. Aiemman tutkimuksen tuottama näkemys romanikulttuurin selkeästä sukupuolien välisestä roolijaosta saa osittaista vahvistusta lauluperinteen kautta - hevos-, viina-, vankila- ja mahtilaulut ovat luonteeltaan maskuliinisia ja kuuluvat miesten repertoaariin, naisten laulustossa taas rakkaus on keskeinen aihepiiri. Jako ei kuitenkaan ulotu tunteiden ilmaisuun, vaan romanikulttuurissa myös miehen on mahdollista ilmaista herkkiä emootioita, eivätkä tytöt ja naiset osoittaudu laulujensa valossa sen tunteellisemmiksi kuin pojat ja miehetkään.

Risto Blomster analysoi artikkelissaan perinnelaulujen musiikillisia piirteitä 1970-luvulla tallennetun äänitemateriaalin pohjalta. Valtaosa traditionaaleista lauluista pohjautuu joko suomalaiseen rekilauluun tai venäläiseen romanssiin. Romanikulttuurin piirissä niihin on kuitenkin liitetty runsaasti omaperäisiä piirteitä siten, että laulujen melodiikka on romanisoitunut, samoin niiden esitystapa. Laulutyylin keskeisiä tyylipiirteitä käsittelevässä yhteisartikkelissaan Åberg ja Blomster toteavat erityisesti glissandon sekä omintakeisen ja helposti tunnistettavan vibraton säilyneen muutospaineissa. Tässä yhteydessä käsittelynsä saavat myös laulujen säestäminen kitaralla ja lauluperinteen välittymisessä tapahtuneet muutokset. 


\section{PASI Enges}

\section{NYKYPÄIVÄN ROMANIMUSIIKKIA JA HENKILÖKUVIA}

Perinnelaulut kuuluvat romanimusiikin yksityiseen puoleen, julkista puolta edustavat esimerkiksi pääasiassa valtaväestölle esityksensä suuntaavat iskelmälaulajat. Kirjan toisen osan otsikkona on Vanhoja ja uusia ilmiöitä, ja se sisältää artikkelit romanien hengellisestä musiikista ja iskelmämusiikista sekä katsauksen romanimusiikkia koskevaan tutkimus- ja lehtikirjoitteluun. Erityisesti helluntaiherätys on vetänyt puoleensa Suomen romaniväestöä ja musiikilla on keskeinen asema myös uskonelämässä. Hengellisen musiikin konteksteissa ryhmärajat vähemmistön ja valtaväestön välillä hämärtyvät, koska yhteinen usko on ryhmänmuodostuksen perusta. Se myös tasoittaa kulttuuriin koodattua sukupuolten välistä eroa tehdessään naisille mahdolliseksi matkustamisen ja hengellisiin kokouksiin osallistumisen naisryhmissä tai jopa yksin.

Julkisuudessa romanimusiikin epäilemättä tunnetuimman ja näkyvimmän osan muodostavat iskelmä- ja erityisesti tangolaulajat, joita on noussut esiintymislavoille ja levylistoille 1950- ja 1960-lukujen taitteesta alkaen. Iskelmälaulajuus on romanimusiikissa uusi ilmiö, jonka taustalla on suomalaisen yhteiskunnan murros 1950-luvulla. Kaupungistuminen ja maaseudun nopea koneellistuminen tekivät tarpeettomiksi romanien perinteiset ammatit, joilla oli ollut oma tärkeä tehtävänsä maalaisyhteisöissä. Erityisesti "mustalaistangosta" tuli tyypillisesti suomalainen estradeilla esitettävän romanimusiikin laji, joka tuli suosituksi myös valtaväestön parissa. Tähän suosioon ja siitä seuranneeseen romaniartistien julkisuuskuvaan liittyy vielä nykyäänkin sekä romantisoivaa eksotismia että eriarvoistavaa kulttuurirasismia.

Risto Blomster käy läpi romaneista ja heidän musiikistaan kirjoitettua aina 1700-luvulta lähtien. Romantiikan ajan taiteet Euroopassa suuntautuivat salaperäiseen Itään ja samaa eksotiikkaa löytyi myös oman vähemmistön parista. Luotiin stereotyyppinen ja todellisuudelle vieras romanius eli "mustalaisuus", jota luonnehtivat sellaiset adjektiivit kuin vapaa, aito, luonnollinen ja tulinen. Tutkimuksen näkökulmasta kysymys romanien alkuperästä oli keskeinen koko 1800-luvun ja 1900-luvun alkupuolen, ja vallalla oli näkemys kulttuurin intialaisista juurista. Evolutionistisen paradigman mukaisesti romanimusiikkia pidettiin alkukantaisena ja kehittymättömänä - samoin kuin tuon perinteen kantajia! Romanistereotypiat olivat myös eri puolilla Eurooppaa kierrelleiden ammattimaisten orkesterien tietoisesti hyödyntämä keino yleisönsä suosion saavuttamiseksi.

Kirjan kolmanteen osaan sisältyy kaksi aiemmin julkaistua henkilökuvaa, molemmat Pekka Laaksosen kynästä ja molemmat nyt laulutekstein täydennettyinä. "Mustalaisparonina" tunnettu Arthur Thesleff oli kasvitieteilijä, mutta myös monilla muilla aloilla kunnostautunut tutkija ja originelli, joka muistetaan ennen kaikkea romanikielen- ja kulttuurin tallentajana. Aiheesta innostuttuaan hän matkusti laajasti ympäri Eurooppaa ja Aasiaa laajentaakseen tietämystään eri maiden romaneista, julkaisi aiheesta useita artikkeleita sekä toimi kansainvälisen Gypsy Societyn presidenttinä. Artikkeliin on liitetty käännöksineen otteita Thesleffin Pohjanmaalta ja Kannakselta taltioimasta romanilaulukokoelmasta, joka nyt tulee ensimmäistä kertaa julkisuuteen. Toinen Laaksosen teksteistä esittelee Saska Borgin, johon kirjoittaja tutustui tehdessään kenttätöitä Sysmässä 1960-luvun lopulla. Artikkelissa tutustutaan sekä Saska 


\section{ROMANIMUSIIKKIA MAHTILAULUISTA TANGOON}

Borgin elämänvaiheisiin että repertoaariin. Sysmäläisen laulua voi kuulla Suomalaisen Kirjallisuuden Seuran ja Love Recordsin alun perin vuonna 1972 julkaisemalla Kaale džambena - Suomen mustalaiset laulavat -levyllä.

\section{MUSIIKIN JA ELÄMÄNTAVAN YKSEYS}

Kirjan artikkeleissa usein toistuva termi on romanius, jonka ymmärrän tarkoittavan sekä ryhmän sisällä tunnistettua olemassaolon ja elämisen tapaa, "romanina olemista", että sitä kriteeristöä, jonka kautta erottaudutaan valtaväestöstä. Suhteessa romaniuteen musiikki näyttäytyy merkittävänä, itse asiassa keskeisenä etnisen identiteetin ilmaisijana. Artikkelikokoelmasta välittyy tekijöiden kunnioittava suhtautumistapa tutkimuskohteeseensa. Mustalaisista puhutaan uudelleenjulkaistuissa artikkeleissa vielä ongelmattomasti, mutta uusissa teksteissä käytetään systemaattisesti poliittisesti korrektia romania (omakielisen rom-sanan mukaisesti). Toisaalta käy ilmi, että etenkin vanhempi sukupolvi vierastaa uutta nimitystä - heille tuttuja endonyymejä ovat kaale tai tumma. Identifioituminen voi tapahtua myös puhumalla yksinkertaisesti "meistä" ja meidän lauluistamme.

Kaiken kaikkiaan Suomen romanimusiikki tarjoilee aiheestaan monipuolisen ja kattavan kuvan. Kirjan painopiste on selkeästi romanien laulumusiikissa, mikä on hyvin perusteltua, sillä arkaaisiakin piirteitä mukanaan kantavan musiikkikulttuurin pohjana on säestyksetön yksin- tai ryhmälaulu. Laulaminen osoittautuu erityisen tärkeäksi kulttuurisen itseilmaisun välineeksi, sillä laulaen on ollut ja on edelleen mahdollista käsitellä teemoja, joista puhuminen ei olisi kulttuurisen soveliaisuussäännöstön mukaista. Useissa kohdissa kirjaa käy ilmi, että romanilaulajat ovat itse hyvin tietoisia musiikkinsa erikoislaatuisuudesta ja pitävät sitä eräänlaisena toisena äidinkielenään. Lapsuudessa omaksuttu kouluttamaton ja luonnollinen musikaalisuus on arvostettua ja sitä pidetään kulttuurissa periytyvänä erityisominaisuutena. Kuvaavia ovat sitaatit "Meillä mustalaisilla on geeneissä se musiikki"- ja "Se [laulaminen] on niin ku tämä romanikieli, se on niin ku meille valmiiks annettu".

Rakenteellisesti kokoelma etenee sujuvasti vanhoista perinnelauluista nykypäivän romanimusiikin muotoihin. Hieman yllättävästi Risto Blomsterin, Raila Halmetojan ja Kai Åbergin yhdessä kokoama luettelo eri arkistoissa olevista romanimusiikkikokoelmista, julkaistuista äänitteistä ja tutkimuksista on sijoitettu kirjan viimeiseksi artikkeliksi, vaikka muista teksteistä poikkeavana sen paikka olisi pikemminkin ollut liitteessä. Luettelo on hyödyllinen apuväline niille, jotka haluavat perehtyä aihepiiriin syvällisemmin tai suunnittelevat tutkimusta siitä. Teoksen lopussa oleva henkilöhakemisto puolustaa paikkaansa; myös asiasanahakemisto olisi ollut tarpeellinen.

Kirja sisältää kohtuullisesti nuottiesimerkkejä ja musiikkiterminologiaa, mutta avautuu lukijalle ilman näiden tuntemustakin. Artikkelikokoelman punaisena lankana on kuitenkin musiikin kytkeytyminen romanien historiaan, elämäntapaan ja sopeutumisprosesseihin yhteiskunnan muutoksissa. Maailman muuttuessa musiikkikulttuurikin 
PASI Enges

muuttuu, mutta Suomen romanimusiikki -artikkelikokoelman perusteella juuri siksi laulamisen traditio jatkuu elinvoimaisena.

Filosofian maisteri Pasi Enges on folkloristiikan päätoiminen tuntiopettaja Turun yliopistossa. 